\section{EFFECTIVE TAX BURDEN ON INVESTMENT AT CORPORATE LEVEL IN MACEDONIA}

ILIJA GRUEVSKI,

STEVAN GABER

Faculty of Economics

"Goce Delcev" University,

Republic of Macedonia

VASILKA GABER

Faculty of Economics

University "Ss. Cyril and Methodius"-Skopje

JEL Classifications: H25, H32, D92

Keywords: Corporate income tax, cost of capital, effective marginal tax rates, effective average tax rates, Republic of Macedonia

\begin{abstract}
This article presents the estimates of effective tax rates on investment at corporate level in Republic of Macedonia in the period from 2006 to 2012. In addition to accomplishing this research, 3 basic and most commonly applied indicators of the corporate income tax (CIT) burden will be used. They are the cost of capital, the effective marginal tax rate (EMTR) and the effective average tax rate (EATR), according to the Devereux-Griffith methodology. The results of the analysis will clearly show that the implemented domestic tax policy reform have transformed this country into one of the most, if not the most tax favorable country for investment in Europe.
\end{abstract}

\title{
Introduction
}

The Corporate Income Tax System in Republic of Macedonia has always been subject of continuous reforms and additional improvements, especially in the period after the country became a candidate for EU membership in 2005. Like the most transition countries, since it experienced a deficit of capital in the period after its independence, Macedonia has chosen to develop a consumption-based corporate income tax. This practically means that the tax burden of corporate income is excessively targeted to its shares that are intended mostly for consumption, while the parts of income whose purpose is to be saved or reinvested are generally levied with lower tax burden or eventually exempted from taxation (Rose and Wiswesser, 1998). The shift in the concept of taxation started in 2006 when a flat tax rate was primarily introduced and lowered at the same time (from $15 \%$ in 2006 to $12 \%$ in 2007 and to $10 \%$ in 2008) and culminated in 2009 when a split rate corporate tax system was implemented. ${ }^{1}$ Despite the fact that the economic crisis gained on intensity in the following years, the government didn't change its tax policy

\footnotetext{
${ }^{1}$ When a split rate corporate tax system is implemented, retained profits are not taxed. In Macedonia, corporate profits are only taxed, if they are distributed with a $10 \%$ tax rate. This measure which is originally called "Tax exemption on undistributed earnings" was basically intended to create strong incentives for reinvestment of the retained profits. Similar concept was implemented in Estonia, also.
} 
course, since no other significant tax code alterations have been done after 2009.

The aim of this article is to evaluate the effect from the tax code derogations as well as the tax policy relevance in Macedonia in the period from 2006 to 2012, with the help of the most reliable effective tax burden measures. According to the European Commission recommendations, the standard methodology is based on the Devereux-Griffith approach (1999). Measurements of the effective tax rates on domestic investment include: the cost of capital, the effective marginal tax rate (EMTR), as well as the effective average tax rate (EATR). Firstly, the paper contains short elaboration and the practical application of the proposed methodology in the case of Macedonia. Secondly, the full analysis of the relevant tax burden indicators is additionally presented. Finally, the comparative approach of the estimated tax rates between Macedonia and the other EU countries is given, before the concluding remarks.

\section{The proposed methodology in the case of Macedonia}

According to Devereux and Griffith (1999, 2002, 2003), the model assumes a hypothetical investment project undertaken by a corporation in the manufacturing sector. The corporation can invest in 5 (five) different assets weighted equally (1.buildings - or industrial buildings; 2 . equipment or machinery; 3. intangibles-especially patents; 4.financial assets; and 5.inventories.). True economic depreciation rates assumed for the assets are: buildings $3.1 \%$, equipment $17.5 \%$, intangibles $15.35 \%$, financial assets $0 \%$ and inventories $0 \%$. The financial strategy of the hypothetical investment project is consisted of 3 (three) different alternative sources of finance which are also weighted equally (1.debt from external lenders; 2.new equity capital; and 3.retained earnings.). EATR is calculated by assuming a pre-tax real rate of return of $20 \%$, real interest rate of $5 \%$ and inflation rate of $2 \%$. The calculation of EATRs in this article considers only the taxes at corporate level (taxes at shareholders level are ignored). This assumes all personal tax rates to be zero. Structure of the corporation is assumed without a controlling company also. Table 1 from the annex below, summarizes the relevant economic parameters assumed for the purpose of calculation of the effective tax rates and Table 2 contains the essential elements of the Macedonian tax code.

The general expression for the EATR in absence of personal taxes is constructed as:

$$
E A T R=\frac{R^{*}-R}{p /(1+r)},
$$

where: $p$ - assumed pre-tax real rate of return, $r$ - real rate of return and $R^{*}$ - economic rent of the project in abcense of tax, measured as: 


$$
R^{*}=\frac{p-r}{1+r}
$$

Term $R$ from the equation, is the economic rent of the project in presence of tax:

$$
R=\frac{\gamma}{1+\rho}\{(p+\delta)(1+\pi)(1-t)-v t \pi-[\rho+\delta(1+\pi)-\pi](1-A)-(1+\rho) e\}+F^{N E}+F^{D E},
$$

where the new symbols are: $\delta$ - true economic depreciation rate, $\pi$ - inflation rate, $i$ - nominal interest rate found from the expression $i=(1+r)(1+\pi), \rho-$ shareholder's discount rate $^{2}, t$ - nominal corporate income tax rate, and $e$ - real estate tax rate, the last both payable in the period in which the investment is undertaken. We must notice that the real estate tax rate (or the property tax rate) in RM, is usually applied only in case of investment in buildings with a rate of $0.1 \%$.

One of the most important variables is the tax discrimination variable $\gamma$, which is used to measure tax discrimination between new equity and distributions. If we consider $m^{d}$ to be the personal tax rate on dividend income, $z$ the effective personal tax rate on capital gains and $c$ the tax credit rate allowed for dividends paid, then:

$$
\gamma=\frac{\left(1-m^{d}\right)}{(1-z)(1-c)}
$$

In absence of personal taxes, since $z=m^{d}=O$, automatically yields $\gamma=1$. This is a case in the period from 2006-2008. In 2009, the implementation of a split rate system generates different value for $\gamma$. Since retained profits are not taxed $(t=0)$ and corporate profits are taxed only when they are distributed with a $10 \%$ tax rate $\left(t^{d}=0.1\right)$, the tax discrimination variable in 2009 is calculated as:

$$
\gamma^{2009}=\frac{\left(1-t^{d}\right)}{(1-t)} \gamma^{2008}=\frac{(1-0,1)}{(1-0)} 1=0.9,
$$

A special attention should be given to the term $v t \pi$. Actually, it reflects the cases of taxation of inventories and financial assets and it depends largely on the method of valuation for tax purposes. In the case when these assets are valued on FIFO basis, than $v=1$, in the case of LIFO, $v=0$, and if average cost method is used, than $v=0.5$. In RM, the treatment of financial assets implies $v$

\footnotetext{
${ }^{2}$ In case of calculation of EATR only at corporate level, personal taxes are assumed to be o, hence, the shareholder's discount rate is identical with the nominal interest rate $\rho=i$.
} 
$=1$, and since the average cost method is in force for the treatment of inventories, in this case $v=0.5$.

Parameter A represents the net present value of tax depreciation allowances for the different assets. Although the Macedonian tax code recognizes all of the standard depreciation methods and gives an opportunity for the specific functional method, the Ministry of finance restricts the choice to the straightline method as the only relevant depreciation method. Depending on the method of depreciation (declining-balance method, inclining balance method or straight-line depreciation method), parameter A might have different values. Here, we give the general expression for the NPV of tax depreciation allowances only for the straight-line depreciation method, since it is the most relevant depreciation method:

$$
A=t \phi\left\{\left(\frac{1}{1+\rho}\right)+\left(\frac{1}{1+\rho}\right)^{2}+\ldots+\left(\frac{1}{1+\rho}\right)^{L}\right\} \text { or } A=t \phi \frac{(1+\rho)^{L}-1}{\rho(1+\rho)^{L}}
$$

where: $L$ - length of the depreciation period (expressed in years) and $\varphi$ depreciation rate for the different assets allowed for tax purposes. In RM, tax depreciation rate for the buildings is taken to be $5 \%$, for the equipment (machinery) $14.28 \%$ and for the intangibles $20 \%$, measured as an equally weighted average rate for each asset group. Translated in years, the lengths of depreciation periods are 20, 7 and 5, consequently. For the other 2 assets (financial assets and inventories), depreciation rates are logically 0.

The financial constraints of investment $F$ depend largely on the source of finance (Devereux and Griffith, 1999). For example, in the case of reinvestment of retained earnings, the project is financed by a reduction in dividend payments in the current period $n$, hence debt and equity issues are unaffected. This implies $F^{R E}$ to be zero. When there is a case of new equity finance, the financial constraints variable $F^{N E}$ is expressed as:

$$
F^{N E}=-\frac{\rho(1-\gamma)(1+e)}{(1+\rho)},
$$

and in in the case of debt finance investment, the financial constraints variable $F^{D E}$ is calculated as:

$$
F^{D E}=\frac{\gamma(1+e)(\rho-i(1-t))}{1+\rho}
$$

In absecne of personal taxes, since $\gamma=1$, implies that $F^{N E}=0$. From 2009 to 2012, when the split rate system is in force, $\gamma=0,9$, hence $F^{N E}$ yields different value, presented below in Table 3 .

The effective marginal tax rate is established as: 


$$
\text { EMTR }=\frac{\tilde{p}-s}{\tilde{p}},
$$

where $p^{\sim}$ is the cost of capital (pre-tax rate of return on investment) defined as:

$$
\tilde{p}=\frac{(1-A)\{\rho+\delta(1+\pi)-\pi\}+v t \pi+(1+\rho) e}{(1+\pi)(1-t)}-\frac{F(1+\rho)}{\gamma(1+\pi)(1-t)}-\delta,
$$

while $s$ represents the post-tax rate of return on savings:

$$
s=\frac{\left[\left(1-m^{i}\right) i-\pi\right]}{(1+\pi)},
$$

Because the personal tax rate on interest income is zero $\left(m^{i}=0\right)$, the posttax rate of return $s$ is identical with the real interest rate $r(s=r=0,05)$. Table 3 summarizes the derived input parameters used for calculation of the EATRs in period 2006-2012.

\section{The relevant tax burden indicators (results and interpretation)}

Table 4, from the annex below, shows the estimated values of the cost of capital in Macedonia in the period 2006-2012. As a general rule, this indicator is important because it reflects the optimal size of an investment. The results indicate that in every case of investment financed with retained earnings and new equity issues, the cost of capital is higher or equal to $5 \%$, which is the level of the real rate of return. The highest value of $5.93 \%$ is measured in 2006, while the lowest of only $5.02 \%$ in the period 2009 to 2012. In case of investment financed with external debt, the values are mostly lower than the real rate of return, ranging from $4.70 \%$ to $5.02 \%$. This means that the domestic tax system subsidizes investment financed with debt compared to the other types of investments. On the other hand, the analysis of the results for the cost of capital on investments by type of asset, points that the investments in intangibles and buildings have the lowest minimum rate of return. Investments in inventories and especially in financial assets represents the group of assets with the opposite conclusion.

The estimated values of effective marginal tax rates (EMTRs) are presented in the annex in the same Table 4. The significance of this measure is seen in the fact that the allocation efficiency of the system depends largely on the effective marginal tax burden levels. Therefore, the EMTR is appropriate for measuring of the extent on the available incentives ${ }^{3}$ built in the system. Concerning the results of the EMTR, we can generalize similar condition as in the previous

3 There are numerous available tax incentives in Macedonia, such as the tax holidays for the Technological Industrial Development Zones (TIDZ) and for the companies that employ disabled workers. In respect with the limited space available in this paper, we'll give more detail information and explanation in some other occasion. 
case of the cost of capital. Basically, investments with retained earnings and new equity issues generate positive values of EMTR, the highest of $15.58 \%$ in 2006, and the lowest of only $0.39 \%$ from 2009 to 2012. Positive values of EMTR indicate that the cost of capital for these investments is higher than the real rate of return, meaning that in these cases there is a positive taxation on the marginal unit of investment. On the contrary, the EMTR on investments covered with external debt shows negative values in the period from 2006 to 2008 , with the highest negative value of $-6.57 \%$ registered in 2006. After that, a small positive value of $0.39 \%$ is measured in the period 2009 to 2012. The negative prefix in the first period indicated on the existence of positive incentives that resulted in values of the cost of capital lower than $5 \%$, automatically subsidizing the marginal investment financed with debt.

Again, Table 4 from the annex below, summarizes the estimated values of effective average tax rates (EATRs) on investments in Macedonia calculated with assumed pre-tax real rate of return of $20 \%$. The analytical value of the EATR arises from its ability to indicate to the part of the corporate income that is being effectively cut by taxation, but, unlike EMTR, the EATR indicates on the effective reduction of the net present value of a profitable, infra-marginal investment. It is an useful instrument for the corporations during the decision making process for evaluation of location specific discrete investment choices.

The results of the EATR by source of finance (see details in annex, Table 4) explicit again, that investments financed with retained earnings and equity issues have the highest values of EATR. Precisely, EATR on investment financed with retained earnings range from $15.23 \%$ in 2006 to $7.61 \%$ in 20092012, while EATR on investment financed with new equity issues vary from $15.23 \%$ in 2006 to $11.09 \%$ in 2009-2012. Investments financed with debt, yet again demonstrate the lowest values ranging from $10.00 \%$ in 2006 to $7.61 \%$ in 2006-2012.

As a conclusion, the implementation of the split rate tax system resulted with lower tax burden on investments financed with retentions (since retained profits are exempt from taxation) and higher burden on investments covered with equity issues (since distributions of profits are taxed). The aim of this strategy was to generate strong incentives for reinvestment of retained profits, and reduce the chances for their consumption in a form of dividend distributions. As a result, the system actually discriminates new equity in favor of retained earnings, although the overall burden remains even lower. Additionally, an interpretation can be given concerning the last, that this measure puts the old mature companies in better position compared to the new ones, because the first relay much more on reinvesting the retained accumulated profits as a source of finance. The previous is illustrated in Figure 1.

The EATR range by asset composition is similar as previously mentioned. In more detail (see Table 4 from the annex below), the EATR on investment in buildings ${ }^{4}$ vary from their highest value of $12.94 \%$ in 2006 to their lowest of

4 Buildings enjoyed relatively high tax privileges at the beginning of the observed period, since construction is considered as one of the sectors with the highest priorities for the Macedonian government. In the following years the government's support for the construction sector was realized more in a form of 
9.15\% in 2009-2012, investments in equipment have slightly higher EATR with a range of values from $13.46 \%$ to $8.68 \%$, the EATR on investment in inventories vary from $14.01 \%$ to $8.68 \%$, financial assets are the least tax favorable investment option with EATR varying from $14.75 \%$ to 8.68 , and finally intangibles represent the other extreme investment option as they enjoy the highest privileges of the tax system. Generally, this categorization is determined from the tax treatment of depreciation allowances for each different asset. This is presented below in Figure 2, which illustrates the process of convergence of the EATR by assets as a result of the implementation of the split rate system. The small difference in the EATR for the buildings in the period 2009-2012 is due to the real estate tax rate, which is applied only for this specific category of assets.

In the following section we give attention on the trend analysis of the relevant tax burden indicators in the observed period. These trends are illustrated in Figure 3. It is clearly shown that the trend lines for the 3 indicators are downward slopping, meaning that there has been decreasing tendencies of their values in the period 2006 to 2012. For example, the overall mean value of the cost of capital has been decreased from $5.51 \%$ to $5.28 \%$, the overall EMTR from $8.2 \%$ to $4.81 \%$ and the overall mean EATR from $13.48 \%$ to $8.77 \%$. It is necessary to mention that these values are extremely low compared to the other countries, especially in the period 2009 to 2012. This is mainly due to lowering of the CIT rates in the relevant period, and exceptionally due to implementation of the split rate tax system. The decreasing values of the indicators, represent a clear picture of the tax policy reforms undertaken for improvement of the overall investment environment in Macedonia in the observed period from 2006 to 2012.

Finally, the analysis of the EATR by country, undoubtedly demonstrates on the comparative advantages of the Macedonian tax system. The data shows (see Table 5 and Figure 4), that Macedonia has the lowest overall EATR in 2012 with value of $8.8 \%$. From the aspect of the level of the EATR, it's a clear indication that RM offers an extremely favorable investment environment. The treatment of investments especially if they are financed with debt and retained earnings makes this country the leader in the observed group from the perspective of tax favorability and economic performance. Therefore, we may conclude that Macedonia represents an exceptionally favorable location for investment as compared to the other countries.

\section{Conclusion}

The aim of this article is to evaluate the effective corporate tax burden on investment at corporate level in Macedonia, according to the methodology based on the Devereux-Griffith approach (1999). Measurements of the effective tax rates on domestic investment include: the cost of capital, the effective marginal tax rate (EMTR), as well as the effective average tax rate (EATR). The

direct economic measures (such as direct investment in infrastructure and buildings) in exchange for the tax incentives which are a typical indirect form of measure. As an example, we refer to the government's project "Skopje 2014" which was developed for revitalization of the Macedonian capital. 
decreasing values of the indicators, represent a clear picture of the tax policy reforms undertaken for improvement of the overall investment environment in Macedonia in the relevant period from 2006 to 2012. The analysis of the EATR by country, undoubtedly demonstrates on the comparative advantages of the Macedonian tax system with its lowest overall EATR of $8.8 \%$ in 2012. We may conclude that, from the aspect of the level of the EATR, it's a clear indication that Macedonia offers an extremely favorable investment environment and represents an exceptionally favorable location for investment as compared to the other countries.

\section{References}

Devereux, M., Griffith, R., Klemm, A., 2002. "Corporate income tax reforms and international tax competition," Economic Policy publications, Vol.17 (35), pp.449-95

Devereux, M., Griffith, R., 1999. The taxation of discrete investment choices, The institute of fiscal studies, Working Paper Series W98/16, Warwick University

Devereux, M., Griffith, R., 2003. "Evaluating tax policy for location decisions,” International Tax and Public Finance, Vol.10(2), pp.107-26

Rose, M., Wiswesser, R., 1998. "Tax reform in transition economies: Experiences from Croatian tax reform process in the 1990s," in: Sørensen, P., (ed.) Public finance in a changing world, London, Houndsmills: Macmillan 


\section{Appendix}

\section{TABLE 1. ASSUMED ECONOMIC PARAMETERS}

\begin{tabular}{lcc}
\hline \hline Parameters: & Symbol & Value \\
\hline True economic depreciation rate & $\delta$ & \\
- industrial buildings & & $3.1 \%$ \\
- equipment (machinery) & & $17.5 \%$ \\
- intangibles & & $15.35 \%$ \\
- financial assets & & $0 \%$ \\
- inventories & $r$ & $5 \%$ \\
\hline Real interest rate & $\pi$ & $2 \%$ \\
\hline Inflation rate & $p$ & $20 \%$ \\
\hline Pre-tax rate of return & &
\end{tabular}

TABLE 2. TAX CODE PARAMETERS

\begin{tabular}{lcc}
\hline \hline Relevant domestic tax parameters: & Symbol & Value \\
\hline Capital allowances (straight-line method): & $\varphi$ & $5 \%$ \\
- industrial buildings ( $\mathrm{L}=20$ years) & & $14.28 \%$ \\
- equipment (machinery) (L=7 years) & & $20 \%$ \\
- intangibles (L=5 years) & $0 \%$ \\
- financial assets (L=0 years) & $0 \%$ \\
- inventories (L=0 years) & $v$ & 0.5 \\
\hline Treatment of inventories (average cost method) & $v$ & 1 \\
\hline Treatment of financial assets & $t$ & $15 \%, 12 \%, 10 \%, 0 \%$ \\
\hline Corporate tax rate (2006, 2007, 2008, 2009- & & $10 \%$ \\
2012) & $t^{d}$ & \\
\hline Split corporate tax rate on distributions (2009- & & $0 \%$ \\
2012) & & $0 \%$ \\
\hline Personal tax rates (assumed to be 0): & $m^{i}$ & $0 \%$ \\
- on interest income & $m^{d}$ & $0 \%$ \\
- on dividend income & $z^{*}$ & $0.1 \%$ \\
- on capital gains & $c$ & \\
\hline Imputation tax credit rate on dividends paid & $e$ & \\
\hline Real estate tax rate (property tax rate) & & \\
\hline Source: CIT code and Nomenclature of depreciation (2006-2012) &
\end{tabular}


TABLE 3. DERIVED INPUT PARAMETERS, 2006-2012

\begin{tabular}{lccccc}
\hline \hline Parameter & Symbol & 2006 & 2007 & 2008 & $2009 / 2012$ \\
\hline Post-tax rate of return & $s$ & 0.05 & 0.05 & 0.05 & 0.05 \\
\hline Shareholder's discount rate & $\rho$ & 0.071 & 0.071 & 0.071 & 0.071 \\
\hline Tax discrimination variable & $\gamma$ & 1 & 1 & 1 & 0.9 \\
\hline Financial constraints variable & $F$ & & & & \\
- retained earnings & $F^{R E}$ & 0 & 0 & 0 & 0 \\
- new equity issues & $F^{N E}$ & 0 & 0 & 0 & -0.00663 \\
- debt & $F^{D E}$ & 0.00995 & 0.00796 & 0.00663 & 0 \\
\hline Allowances & $A$ & & & & \\
- buildings & $A^{\text {bui }}$ & 0.0788 & 0.0631 & 0.0526 & 0 \\
- equipment (machinery) & $A^{\text {equ }}$ & 0.1151 & 0.0920 & 0.0767 & 0 \\
- intangibles & $A^{\text {int }}$ & 0.1227 & 0.0981 & 0.0818 & 0 \\
- financial assets & $A^{\text {fin }}$ & 0 & 0 & 0 & 0 \\
- inventories & $A^{\text {inv }}$ & 0 & 0 & 0 & 0 \\
\hline
\end{tabular}

Source: Author's calculations

TABLE 4. CORPORATE INCOME TAX BURDEN INDICATORS IN MACEDONIA, 2006-2012 (\%)

\begin{tabular}{|c|c|c|c|c|c|c|c|c|c|c|c|c|}
\hline \multirow{2}{*}{ 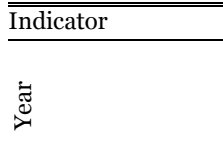 } & \multicolumn{4}{|c|}{ The Cost of capital } & \multicolumn{4}{|c|}{ EMTR } & \multicolumn{4}{|c|}{ EATR } \\
\hline & $\begin{array}{l}\text { : } \\
:\end{array}$ & $\begin{array}{l}\hat{0} \\
\text { ¿ }\end{array}$ & $\begin{array}{l}\infty \\
\stackrel{0}{0} \\
\text { iv }\end{array}$ & 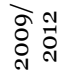 & : & مे & \begin{tabular}{l}
$\infty$ \\
$\stackrel{0}{0}$ \\
\multirow{N}{*}{}
\end{tabular} & 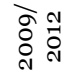 & \begin{tabular}{l} 
: \\
$:$ \\
\multirow{2}{*}{}
\end{tabular} & 仓̊․․ & $\begin{array}{l}\infty \\
\stackrel{0}{0} \\
\stackrel{\text { N }}{1}\end{array}$ & 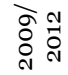 \\
\hline Buildings (mean) & 5.39 & 5.32 & 5.28 & 5.36 & $\underline{6.06}$ & 5.36 & 4.89 & 6.29 & 12.94 & 10.46 & 8.56 & 9.1 .5 \\
\hline - retained earnings & 5.80 & 5.64 & 5.54 & 5.10 & $\overline{13.79}$ & 11.34 & 9.74 & 1.96 & 14.68 & $\overline{11.85}$ & 9.96 & 7.99 \\
\hline - new equity issues & 5.80 & 5.64 & 5.54 & 5.88 & 13.79 & 11.34 & 9.74 & 14.96 & 14.68 & 11.85 & 9.96 & 11.48 \\
\hline - debt & 4.57 & 4.69 & 4.77 & 5.10 & -9.41 & -6.61 & -4.82 & 1.96 & 9.45 & 7.67 & 5.78 & 7.99 \\
\hline Equipment (mean) & 5.51 & 5.40 & 5.32 & 5.26 & $\underline{8.16}$ & 6.71 & 5.61 & 4.45 & 13.46 & 10.77 & $\underline{8.98}$ & $\underline{8.68}$ \\
\hline - retained earnings & 5.92 & 5.72 & 5.58 & 5.00 & 15.54 & 12.58 & 10.39 & 0.00 & 15.20 & 12.17 & 10.14 & 7.52 \\
\hline - new equity issues & 5.92 & $5 \cdot 72$ & 5.58 & $5 \cdot 77$ & 15.54 & 12.58 & 10.39 & $13 \cdot 34$ & 15.20 & 12.17 & 10.14 & 11.00 \\
\hline - debt & 4.69 & 4.76 & 4.81 & 5.00 & -6.61 & -5.04 & -3.95 & 0.00 & 9.97 & 7.99 & 6.66 & 7.52 \\
\hline Intangibles (mean) & 5.24 & 5.19 & 5.15 & 5.26 & 3.29 & 2.89 & 2.47 & 4.4 .5 & 12.31 & 9.86 & $\underline{8.21}$ & $\underline{8.68}$ \\
\hline - retained earnings & 5.65 & $5 \cdot 51$ & 5.41 & 5.00 & 11.50 & $\overline{9.25}$ & 7.58 & 0.00 & $\overline{14.05}$ & 11.25 & $\overline{9.37}$ & $\overline{7.52}$ \\
\hline - new equity issues & 5.65 & $5 \cdot 51$ & 5.41 & $5 \cdot 77$ & 11.50 & 9.25 & 7.58 & 13.34 & 14.05 & 11.25 & 9.37 & 11.00 \\
\hline - debt & 4.42 & 4.55 & 4.64 & 5.00 & -13.12 & -9.89 & -7.75 & 0.00 & 8.82 & 7.07 & 5.89 & 7.52 \\
\hline Fin. assets (mean) & 5.82 & 5.63 & 5.51 & 5.26 & 13.16 & 10.5 .5 & $\underline{8.90}$ & 4.45 & 14.74 & 11.80 & 9.84 & $\underline{8.68}$ \\
\hline - retained earnings & 6.23 & 5.94 & $5 \cdot 77$ & 5.00 & 19.74 & 15.82 & 13.35 & 0.00 & 16.49 & 13.19 & 11.00 & 7.52 \\
\hline - new equity issues & 6.23 & $5 \cdot 94$ & $5 \cdot 77$ & $5 \cdot 77$ & 19.74 & 15.82 & 13.35 & $13 \cdot 34$ & 16.49 & 13.19 & 11.00 & 11.00 \\
\hline - debt & 5.00 & 5.00 & 5.00 & 5.00 & 0.00 & 0.00 & 0.00 & 0.00 & 11.23 & 9.02 & 7.52 & 7.52 \\
\hline Inventories (mean) & 5.64 & 5.50 & 5.40 & 5.26 & 10.32 & 8.4 .3 & 7.02 & 4.4 .5 & 14.01 & $\underline{11.22}$ & 9.35 & $\underline{8.68}$ \\
\hline - retained earnings & 6.05 & 5.82 & 5.66 & 5.00 & 17.35 & 14.09 & 11.66 & 0.00 & 15.75 & 12.61 & 10.51 & 7.52 \\
\hline - new equity issues & 6.05 & 5.82 & 5.66 & $5 \cdot 77$ & 17.35 & 14.09 & 11.66 & 13.34 & 15.75 & 12.61 & 10.51 & 11.00 \\
\hline - debt & 4.82 & 4.86 & 4.89 & 5.00 & -3.73 & -2.88 & -2.25 & 0.00 & 10.53 & 8.43 & 7.03 & 7.52 \\
\hline Ret. earn. (mean) & 5.93 & 5.73 & 5.59 & 5.02 & 15.58 & 12.62 & $\underline{10.54}$ & 0.39 & 15.23 & $\underline{12.21}$ & $\underline{10.20}$ & 7.61 \\
\hline New eq. is.(mean) & 5.93 & 5.73 & 5.59 & 5.79 & $\underline{15.58}$ & $\underline{12.62}$ & $\underline{10.54}$ & $\underline{13.66}$ & 15.23 & $\underline{12.21}$ & $\underline{10.20}$ & $\underline{11.09}$ \\
\hline Debt (mean) & 4.70 & 4.77 & 4.82 & 5.02 & -6.57 & -4.88 & -3.75 & 0.39 & 10.00 & 8.04 & 6.57 & 7.61 \\
\hline
\end{tabular}


TABLE 5. EATR BY COUNTRY, 2012 (\%)

\begin{tabular}{lccccc}
\hline \hline Below 20\% & EATR & Between 20\%-30\% & EATR & Above 30\% & EATR \\
\hline Macedonia & $\underline{8.8}$ & Denmark & 22.0 & Malta & 32.2 \\
\hline Bulgaria & 9.0 & Austria & 23.0 & Spain & 32.4 \\
\hline Cyprus & 11.2 & Sweden & 23.2 & France & 34.2 \\
\hline Latvia & 12.2 & Finland & 23.3 & USA & 36.5 \\
\hline Lithuania & 12.7 & Luxembourg & 24.9 & Japan & 40.1 \\
\hline Ireland & 14.4 & Canada & 25.0 & & \\
\hline Romania & 14.8 & Italy & 25.1 & & \\
\hline Slovenia & 16.4 & United Kingdom & 25.2 & & \\
\hline Croatia & 16.5 & Belgium & 26.3 & Average: & \\
\hline Estonia & 16.5 & Norway & 26.5 & & \\
\hline Czech Republic & 16.7 & Portugal & 27.1 & & \\
\hline Slovakia & 16.8 & Netherlands & 27.5 & & \\
\hline Greece & 17.5 & Germany & 28.2 & & \\
\hline Poland & 17.5 & & & & \\
\hline Turkey & 17.9 & & & & \\
\hline Switzerland & 18.7 & & & & \\
\hline Hungary & 19.3 & & & & \\
\hline Source: ZEW (2012), author's calculations & & & & \\
\hline
\end{tabular}


FIGURE 1. EATR BY SOURCE OF FINANCE IN RM, 2006-2012 (\%)

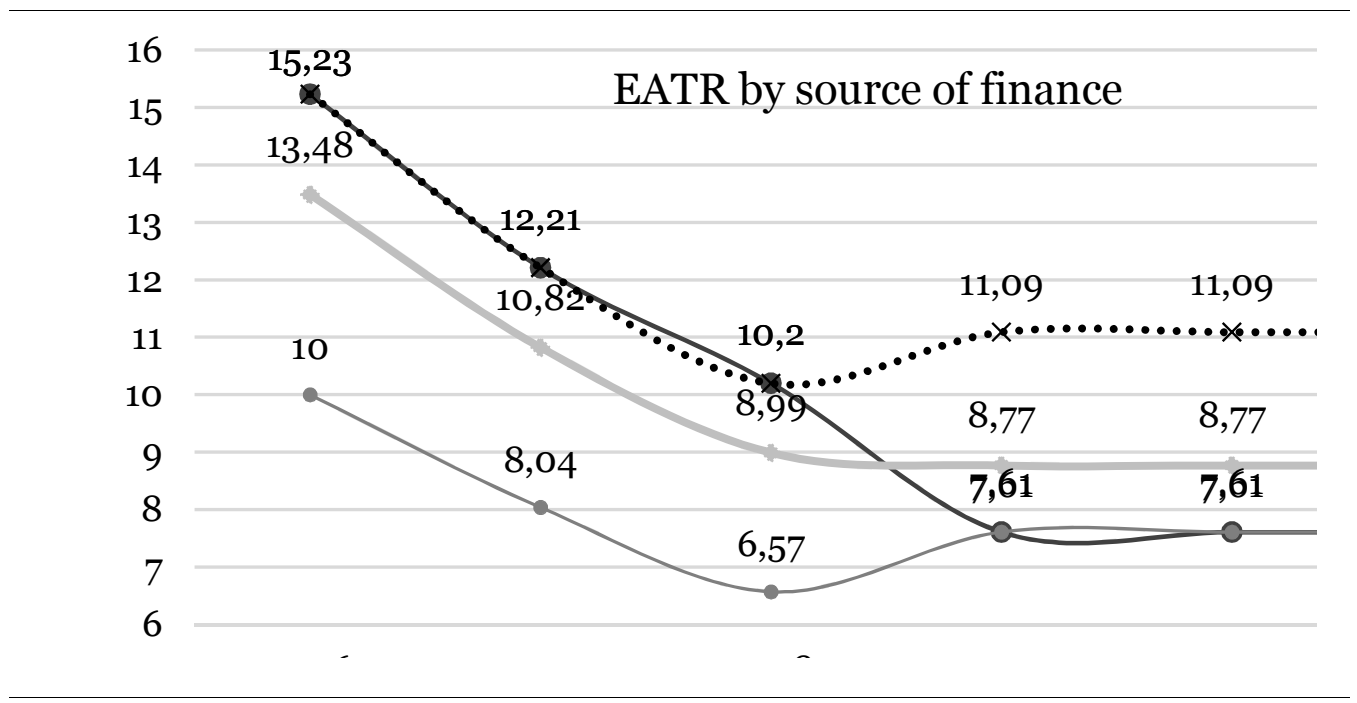

Source: Author's calculations

FIGURE 2. EATR BY ASSET IN RM, 2006-2012 (\%)

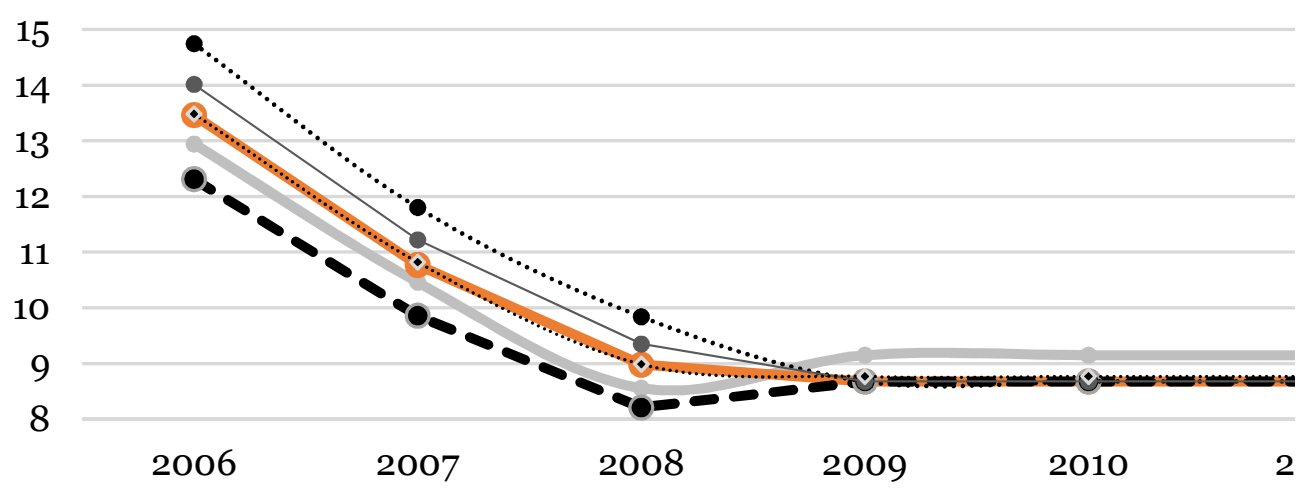

Source: Author's calculations 
FIGURE 3. THE COST OF CAPITAL, EMTR AND EATR (OvERALL MEAN) (\%)

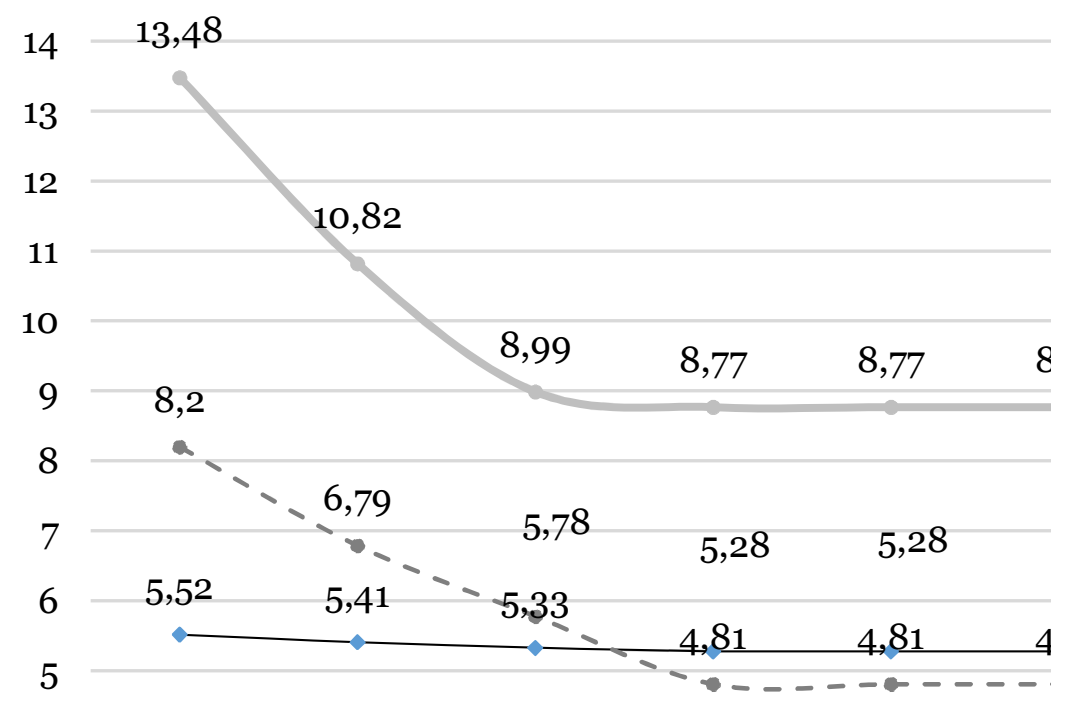

Source: Author's calculations

FIGURE 4. EATR BY COUNTRY

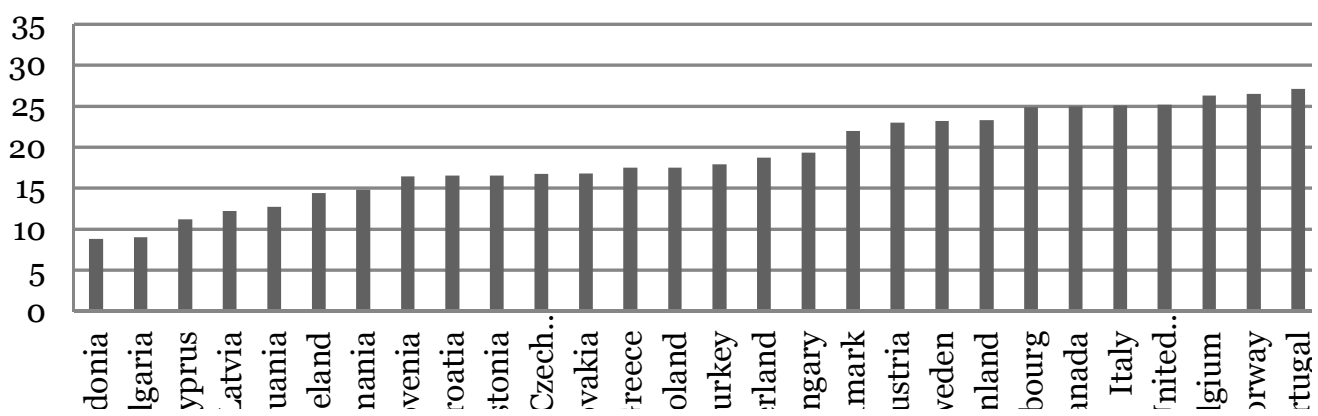

Source: ZEW (2012), author's calculations 